Article

\title{
Phenolic Compounds in Chilean Mistletoe (Quintral, Tristerix tetrandus) Analyzed by UHPLC-Q/Orbitrap/MS/MS and Its Antioxidant Properties
}

\author{
Mario J. Simirgiotis ${ }^{1, *}$, Cristina Quispe ${ }^{2}$, Carlos Areche ${ }^{3}$ and Beatriz Sepúlveda ${ }^{4}$ \\ 1 Laboratorio de Productos Naturales, Departamento de Química, Facultad de Ciencias Básicas, \\ Universidad de Antofagasta, Av. Coloso S-N, Antofagasta 1240000, Chile \\ 2 Facultad de Ciencias de la Salud, Universidad Arturo Prat, Casilla 121, Iquique 1110939, Chile; \\ elquispe@unap.cl \\ 3 Departamento de Química, Facultad de Ciencias, Universidad de Chile, Casilla 653, Santiago 7800024, Chile; \\ areche@uchile.cl \\ 4 Departamento de Ciencias Químicas, Universidad Andres Bello, Campus Viña del Mar, Quillota 980, \\ Viña del Mar 2520000, Chile; bsepulveda@uc.cl \\ * Correspondence: mario.simirgiotis@uantof.cl; Tel.: +56-55-637-229; Fax: +56-55-637-457
}

Academic Editor: Derek J. McPhee

Received: 25 January 2016 ; Accepted: 18 February 2016 ; Published: 23 February 2016

\begin{abstract}
Mass spectrometry has become a method of choice to characterize bioactive compounds in biological samples because of its sensitivity and selectivity. Hybrid ultra-HPLC hyphenated with Orbitrap mass analyzer is an innovative state of the art technology that allows fast and accurate metabolomic analyses. In this work the metabolites of a Chilean mistletoe endemic to the VIII region of Chile were investigated for the first time using UHPLC mass analysis (UHPLC-PDA-HESI-Orbitrap $M^{n}{ }^{n}$. The anthocyanins, together with the non-pigmented phenolics were fingerprinted and correlated with the antioxidant capacities measured by the bleaching of the DPPH radical, the ferric reducing antioxidant power (FRAP), the superoxide anion scavenging activity assay (SA), and total content of phenolics, flavonoids and anthocyanins measured by spectroscopic methods. Six anthocyanins were identified, and among them, the 3-O-glycosides of delphinidin and cyanidin were the major ones. In addition, several phenolic acids (including feruloylquinic acid, feruloyl glucose, chlorogenic acid) and several flavonols (luteolin, quercetin, apigenin, isorhamnetin and glycoside derivatives) were also identified. The mistletoe leaves showed the highest antioxidant activity as measured by the DPPH radical bleaching, ferric reducing antioxidant power and superoxide anion scavenging activity tests $(13.38 \pm 0.47 \mu \mathrm{g} / \mathrm{mL}, 125.32 \pm 5.96 \mu \mathrm{molTE} / \mathrm{g}$ DW and $84.06 \pm 4.59$ at $100 \mu \mathrm{g} / \mathrm{mL}$, respectively).
\end{abstract}

Keywords: muérdago; quintral del álamo; anthocyanins; phenolic acids; flavonoids; antioxidants; ultra HPLC-MS

\section{Introduction}

The genus Tristerix comprises 11 species growing only in South America in places near the Andes Mountains from Chile-Argentina to Colombia and Ecuador. Tristerix tetrandus Mart. (Loranthaceae, local name quintral or quintral del álamo) is a medicinal mistletoe species native to southern Argentina, and central and southern Chile. It is a parasite plant of aspen (Populus sp.) colliguay (Colliguaya odorifera) Maqui (Aristotelia chilensis) willow (Salix sp.) and other native Chilean species. The mistletoe plants are often gathered by local collectors, dried and sold in local markets. The 
study of this plant is important because this Chilean mistletoe has traditionally been used in alternative medicine as an anti-inflammatory, digestive [1], hemostatic and hypocholesterolemic [2] remedy and as an anxiolytic agent [3]. The related mistletoe Tristerix corimbosus is used also as an astringent [3]. Anthocyanins, which belong to the flavonoids subclass, are well known pigmented bioactive compounds [4]. They are widely distributed in fruits and vegetables, such as blueberries, blackberries, raspberries, strawberries, blackcurrants, elderberries, grapes, cranberries, red cabbage, red radishes, and spinach [5]. They are very stable in acidic conditions ( $\mathrm{pH} 2$ ) in which they exist as red-colored flavylium (2-phenylbenzopyrilium) cations [5,6]. These compounds, including their associated flavonoids and phenolic acids, have demonstrated ability to protect against a myriad of human diseases, and present several beneficial effects such as antioxidant, anti-allergic, antimicrobial, anti-inflammatory, anti-hyperglycemic and anticancer activities [5,7-12], among others. The separation and characterization of phenolics in native plants is important for further research since they can be important for the preparation of nutraceuticals with some of the mentioned activities. The use of liquid chromatography (HPLC, UPLC, UHPLC) coupled to several mass spectrometers such as time of flight (TOF or Q-TOF), quadrupole-Orbitrap (Q or Q-OT), triple quadrupole (TQ) or quadrupole-electrospray ionization (Q-ESI) for metabolic profiling and biological analysis in dietary supplements, plants, fruits and vegetables has increased in the last years [13-18]. The hyphenated liquid chromatography-mass spectrometry (LC-MS) methods are superior to gas chromatography-mass spectrometry (GC-MS) methods since no prior derivatization of polar samples (bearing hydroxyl and carboxyl groups) is required [19]. Quality control of herbal drugs and medicinal plants is also performed with LC-MS [13,15]. Indeed, LC-MS was used for the analysis of carotenoids [20], anthocyanins [21], phenolic acids [22] and alkaloids [23] in edible fruits and flowers, among other constituents. Since we were not able to find LC-MS analyses nor reports on phytochemical compounds from this mistletoe species or related ones, and in continuation of our search for interesting polyphenols and other bioactive compounds in native Chilean plants [24-28], in the present work the polyphenolic fingerprints and phenolic content of the leaves and flowers of this species (Figure 1) from the VIII region of Chile were correlated with the antioxidant capacities measured by the bleaching of the DPPH radical, the ferric reducing antioxidant power (FRAP), the superoxide anion scavenging activity assays (SA). The compounds were identified for the first time with the help of PDA analysis and high resolution Orbitrap mass spectrometry (HPLC-ESI-OT-MS) plus comparison with authentic standards.

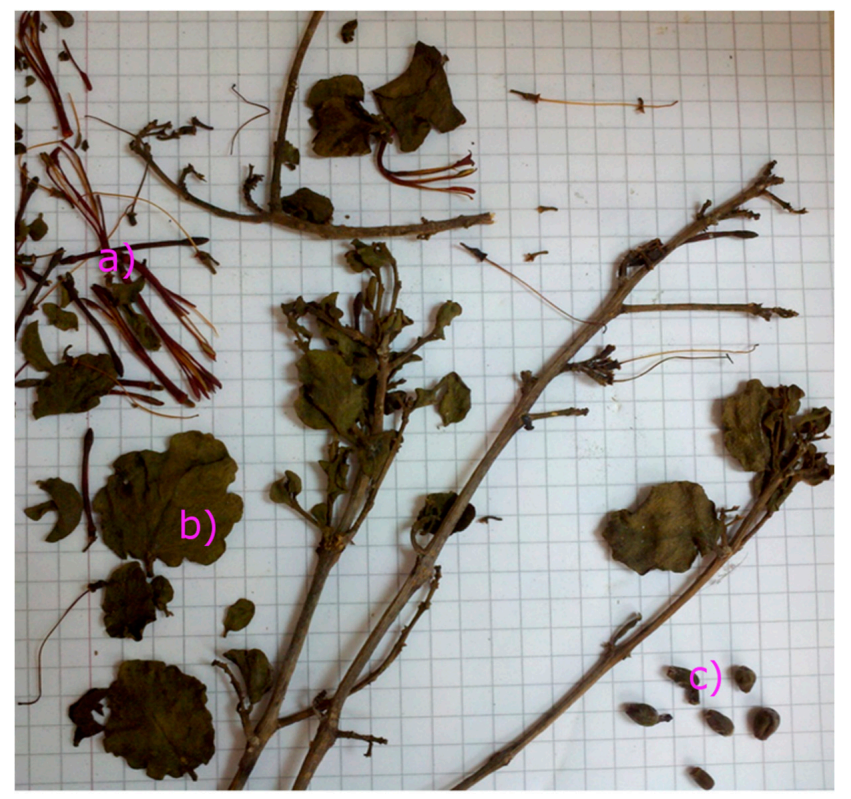

Figure 1. Pictures of an herborized sample of T. tetrandus collected in the VIII region of Chile in 2012. (a) Flowers; (b) leaves; (c) fruits. 


\section{Results and Discussion}

\subsection{Antioxidant Capacity and Total Phenolics, Anthocyanin and Flavonoids Contents}

Three antioxidant assays were employed for this study: the DPPH antiradical activity assay, the superoxide anion inhibition assay, and the ferric reducing activity measured as micromoles of the standard Trolox (Table 1). The antioxidant capacities were supported by the measurement of total anthocyanins in the flowers (TAC), as well as the phenolic (TPC) and flavonoid (TFC) contents in flowers and leaves. For the TPC assay, it has to be stressed that the Folin-Ciocalteu reagent employed reacts with all the oxidants present in the plant extract. Consequently, depending on the extract, this method could overestimate the real phenolic level in the extract. Therefore, data for TPC obtained with the Folin-Ciocalteu's method could be artefactual and the interpretation of the results erroneous [29], for this reason we have supported the results of this assay with the other complementary ones. The leaves showed more antiradical DPPH quenching activity than the flowers, possibly due to the quantity of phenolics (Table 1) found in the leaves. The DPPH value of T. tetrandus leaves was close to that of standard cyanidin-3-glucoside (Table 1) and the synthetic antioxidant butylated hydroxytoluene $(\mathrm{BHT}, 61.13 \mu \mathrm{M})$ [30]. The European mistletoe Viscum album has been extensively studied and the antioxidant activity already reported [31-34], indeed, several studies showed that V. album possess remarkable cholinesterase and tyrosinase inhibitory and antioxidant properties [32]. The TPCs of T. tetrandus leaves were close to that exhibited by V. album L. ssp. album hosting Cerasus vulgaris Miller (Sourcherry), Pinus nigra Arn., (Pine) and Crataegus sp. (around 31, 33 and 37 mg GAE per g extract respectively) [32]. It was also close to that reported from Nolana aplocarioides from Northern Chile (around $30 \mathrm{mg}$ per g) [35]. The TPC of the leaves was also close to that reported for blackberry (Rubus ulmifolium) bud preparations $(350 \pm 8 \mathrm{mg} / 100 \mathrm{~g}$ fresh weight, considering 90 percent of water loss) [36] and was higher to that reported for the superfruit goji $(281.91 \mathrm{mg} / 100 \mathrm{~g}$ fresh weight) [37]. The TFC was also close to the value reported for Nolana aplocarioides (around $22 \mathrm{mg}$ quercetin per $\mathrm{g}$ dry weight) [35]. The TPC and FRAP activity of the flowers was similar to that reported for flowers of Helianthus annus [38]. The TAC of the flowers was close to that of standard cyanidin-3-glucoside (Table 1), and was also close to that reported from the Chilean berries Luma apiculata (15.24 $\pm 1.29 \mathrm{mg}$ cyanidin 3-O-glucoside/g dry weight) [39]. The TAC of the flowers was also double to that reported for the Black Diamond blackberry (Rubus fruticosus) variety $(119.3 \pm 1.2 \mathrm{mg} / 100 \mathrm{~g}$ fresh weight, considering 90 percent of water loss) [40] and similar to black currant (Ribes nigrus) var. Black Down (170.0 $\pm 1.7 \mathrm{mg} / 100 \mathrm{~g}$ fresh weight) [41]. The SAA scavenging of the leaves was somehow lower to that reported for leaves of strawberries $(67.60 \% \pm 1.01 \%$ inhibition) [42].

\subsection{MS-PDA Identification of Phenolic Acids in Chilean Mistletoe (Lorantaceae) From Southern Chile}

The hybrid machine used in this study combines the rapid separation of the ultra-HPLC technique with photodiode (PDA) detection with flow rates up to $2 \mathrm{~mL}$ per minute, zero dead volume, the effective ionization of the heated electrospray probe (HESI II), the high resolving power performance of the orbital trap (Orbitrap, OT), and selectivity of a quadrupole, (reaching resolutions of up to $70,000 \mathrm{FWHM}$ at $m / z 200$ ), and the outstanding diagnostic power of a high resolution collision (HCD) cell. Qualitative data regarding the phenolic compounds of mistletoe extracts are shown in Table 2. We have identified 28 compounds in the leaves and six in the flowers. The compounds in the flowers and leaves were detected and identified using UHPLC with total ion current (TIC) in positive mode for anthocyanins and negative mode for the other phenolic compounds using OT-HESI-MS (Table 2) and UV-visible data (PDA, Figure 2, Table 2). 
Table 1. Scavenging of the 1,1-diphenyl-2-picrylhydrazyl Radical (DPPH), Ferric Reducing Antioxidant Power (FRAP), Superoxide Anion scavenging activity (SAA), Total Phenolic Content (TPC), Total Flavonoid Content (TFC), Total Anthocyanin Content (TAC), and Extraction Yields of a mistletoe from the VIII Region of Chile.

\begin{tabular}{|c|c|c|c|c|c|c|c|}
\hline Species & DPPH $^{-a^{a}}$ & FRAP $^{b}$ & SAA $^{\mathrm{c}}$ & $\operatorname{TPC}^{d}$ & TFC $^{\mathrm{e}}$ & TAC $^{f}$ & Extraction Yields (\%) 8 \\
\hline T. tetrandus leaves & $13.38 \pm 0.47$ & $125.32 \pm 5.96$ & $84.06 \pm 4.59$ & $37.34 \pm 0.92$ & $26.77 \pm 2.76$ & - & 10.16 \\
\hline T. tetrandus flowers & $23.40 \pm 0.40$ & $85.32 \pm 3.22$ & $57.24 \pm 4.36 b$ & $24.60 \pm 1.12$ & $17.54 \pm 1.75$ & $17.32 \pm 1.42$ & 8.83 \\
\hline Gallic acid ${ }^{\mathrm{h}}$ & $1.47 \pm 0.05(7.99 \pm 0.99 \mathrm{mM})$ & $143.2 \pm 6.67$ & $97.55 \pm 1.53$ & - & - & - & - \\
\hline Quercetin $^{\mathrm{h}}$ & $9.69 \pm 0.19(32.01 \pm 0.62 \mathrm{mM})$ & $91.12 \pm 5.27$ & $61.72 \pm 1.18 c$ & - & - & - & - \\
\hline Cyanidin 3-O-glucoside ${ }^{\mathrm{h}}$ & $28.67 \pm 0.22(59.23 \pm 0.47 \mathrm{mM})$ & $82.19 \pm 4.87$ & $56.48 \pm 1.06 b, c$ & - & - & - & - \\
\hline
\end{tabular}

${ }^{\mathrm{a}}$ Antiradical DPPH activities are expressed as $\mathrm{IC}_{50} \mathrm{in} \mathrm{mg} / \mathrm{mL}$ for extracts and compounds; ${ }^{\mathrm{b}}$ Expressed as mM trolox equivalents/g dry weight; ${ }^{\mathrm{c}}$ Expressed in percentage scavenging of superoxide anion at $100 \mathrm{mg} / \mathrm{mL} ;{ }^{d}$ Total phenolic content (TPC) expressed as mg gallic acid/g dry weight; ${ }^{e}$ Total flavonoid content (TFC) expressed as mg quercetin/ g dry weight ${ }^{f}$ Anthocyanin content (TAC) expressed as mg cyanidin 3-O-glucoside/g dry weight; ${ }^{g}$ Extraction yields expressed in percent $W / W$ extraction on the basis of freeze dried material

${ }^{\mathrm{h}}$ Used as standard antioxidants. Values in the same column marked with the same letter are not significantly different (at $\left.p<0.05\right)$. 
Table 2. Identification of Phenolic Compounds in Tristerix tetrandus leaves and flowers by LC-PDA-HR-OT-ESI-MS Data.

\begin{tabular}{|c|c|c|c|c|c|c|c|}
\hline Peak\# & Uv Max & Tentative Identification & Molecular Formula & Retention Time (min) & Theoretical Mass $(\mathrm{m} / \mathrm{z})$ & Measured Mass $(\mathrm{m} / \mathrm{z})$ & Other Ions $(\mathrm{m} / \mathrm{z})$ \\
\hline 1 & - & Quinic acid & $\mathrm{C}_{7} \mathrm{H}_{11} \mathrm{O}_{6}{ }^{-}$ & 2.1 & 191.0561 & 191.0551 & \multirow{4}{*}{$\begin{array}{c}191.0555 \text { (Quinic acid } \\
\mathrm{C}_{7} \mathrm{H}_{11} \mathrm{O}_{6}-\text { ) } \\
707.1825[2 \mathrm{M}-\mathrm{H}]^{-} \\
191.0552\end{array}$} \\
\hline 2 & 325 & Caffeoyl-glucose & $\mathrm{C}_{15} \mathrm{H}_{17} \mathrm{O}_{9}^{-}$ & 2.3 & 341.0878 & 341.0870 & \\
\hline 3 & 236,326 & 3-O-caffeoylquinic acid (3-CQA)* & $\mathrm{C}_{16} \mathrm{H}_{17} \mathrm{O}_{9}^{-}$ & 3.0 & 353.0878 & 353.0873 & \\
\hline $\begin{array}{l}4 \\
5 \\
6\end{array}$ & $\begin{array}{l}236,326 \\
275 \\
280\end{array}$ & $\begin{array}{l}\text { Caffeoyl-shikimic acid } \\
\text { p-Coumaric acid } \\
(+) \text {-Catechin } *\end{array}$ & $\begin{array}{l}\mathrm{C}_{16} \mathrm{H}_{15} \mathrm{O}_{8^{-}} \\
\mathrm{C}_{16} \mathrm{H}_{17} \mathrm{O}_{9}^{-} \\
\mathrm{C}_{15} \mathrm{H}_{13} \mathrm{O}_{6}^{-}\end{array}$ & $\begin{array}{l}3.2 \\
4.1 \\
4.6\end{array}$ & $\begin{array}{c}335.0532 \\
163.0401 \\
289.07176\end{array}$ & $\begin{array}{l}335.0766 \\
163.0390 \\
289.0715\end{array}$ & \\
\hline 7 & 254,354 & Rutin* & $\mathrm{C}_{27} \mathrm{H}_{29} \mathrm{O}_{16}{ }^{-}$ & 4.9 & 609.1461 & 609.1449 & \multirow{2}{*}{$\begin{array}{l}\text { 463.0870, 301.0344 } \\
\text { (Quercetin) }\end{array}$} \\
\hline $\begin{array}{c}8 \\
9 \\
10\end{array}$ & $\begin{array}{c}280 \\
240,325 \\
280\end{array}$ & $\begin{array}{c}\text { Epigallocatechin } \\
\text { Feruloyl quinic acid (3-FQA) } \\
\text { Gallocatechin }\end{array}$ & $\begin{array}{l}\mathrm{C}_{15} \mathrm{H}_{13} \mathrm{O}_{7}^{-} \\
\mathrm{C}_{17} \mathrm{H}_{19} \mathrm{O}_{9}^{-} \\
\mathrm{C}_{15} \mathrm{H}_{13} \mathrm{O}_{7}^{-}\end{array}$ & $\begin{array}{l}5.5 \\
6.2 \\
8.5\end{array}$ & $\begin{array}{l}305.0667 \\
367.1034 \\
305.0667\end{array}$ & $\begin{array}{l}305.0304 \\
367.1028 \\
305.0301\end{array}$ & \\
\hline 11 & 254,354 & Quercetin-3-O-glucose * & $\mathrm{C}_{21} \mathrm{H}_{19} \mathrm{O}_{12}^{-}$ & 12.2 & 463.0882 & 463.0877 & \multirow{2}{*}{$\begin{array}{l}300.0276 \text { (Quercetin } \\
\mathrm{C}_{15} \mathrm{H}_{9} \mathrm{O}_{7}^{-} \text {) } \\
300.0276 \text { (Quercetin } \\
\mathrm{C}_{15} \mathrm{H}_{9} \mathrm{O}_{7}^{-} \text {) }\end{array}$} \\
\hline 12 & 254,354 & Quercetin-3-O-pentose * & $\mathrm{C}_{20} \mathrm{H}_{17} \mathrm{O}_{11}^{-}$ & 12.5 & 433.1033 & 433.2019 & \\
\hline $\begin{array}{l}13 \\
14\end{array}$ & $\begin{array}{l}254,354 \\
254,354\end{array}$ & $\begin{array}{c}\text { Apiin } \\
p \text {-Coumaroyl malate }\end{array}$ & $\begin{array}{l}\mathrm{C}_{26} \mathrm{H}_{27} \mathrm{O}_{14}- \\
\mathrm{C}_{13} \mathrm{H}_{11} \mathrm{O}_{7}-\end{array}$ & $\begin{array}{l}14.4 \\
15.3\end{array}$ & $\begin{array}{l}563.1406 \\
279.0510\end{array}$ & $\begin{array}{l}563.1382 \\
279.0507\end{array}$ & \\
\hline 15 & 254,354 & Quercetin-3-O-glucosyl-derivative & $\mathrm{C}_{27} \mathrm{H}_{23} \mathrm{O}_{16}-$ & 16.5 & 615.0843 & 615.0983 & \\
\hline 16 & 236,329 & di-O-Caffeoylquinic acid (di-CQA) & $\mathrm{C}_{25} \mathrm{H}_{23} \mathrm{O}_{12}{ }^{-}$ & 17.2 & 515.1195 & 515.1192 & \\
\hline 17 & 236,326 & 5-O-Caffeoylquinic acid (3-CQA)* & & 18.0 & 353.0878 & 353.0876 & \\
\hline 18 & & Oxylipin (trihydroxyoctadecadienoic acid) & $\mathrm{C}_{18} \mathrm{H}_{31} \mathrm{O}_{5}^{-}$ & 19.2 & 327.2146 & 327.2144 & \\
\hline 19 & 260 & Oxylipin (trihydroxyoctadecaenoic acid) & $\mathrm{C}_{18} \mathrm{H}_{33} \mathrm{O}_{5}^{-}$ & 22.0 & 329.2147 & 329.2322 & \\
\hline 20 & 254,354 & Delphinidin-3-O-glucose & $\mathrm{C}_{21} \mathrm{H}_{21} \mathrm{O}_{12}+$ & 22.2 & 465.1033 & 465.1104 & 303.0162 (Delphinidin) \\
\hline 21 & & Naringenin-7-O-glucoside & $\mathrm{C}_{21} \mathrm{H}_{21} \mathrm{O}_{10}-$ & 24.9 & & & \\
\hline 22 & 254,354 & Cyanidin-3-O-glucose & $\mathrm{C}_{21} \mathrm{H}_{21} \mathrm{O}_{11}^{+}$ & 24.8 & 449.1135 & 449.1149 & 287.0567 (Cyanidin) \\
\hline 23 & 254,354 & Isorhamnetin-3-O-galactose & $\mathrm{C}_{22} \mathrm{H}_{21} \mathrm{O}_{12}^{-}$ & 25.0 & 477.1038 & 477.1031 & \\
\hline 24 & 236,329 & di-O-Caffeoylquinic acid (di-CQA) & $\mathrm{C}_{25} \mathrm{H}_{23} \mathrm{O}_{12}-$ & 25.2 & 515.1195 & 515.1189 & \\
\hline 25 & 254,354 & Malvidin * & $\mathrm{C}_{17} \mathrm{H}_{15} \mathrm{O}_{7}-$ & 25.4 & 331.0123 & 331.0117 & \\
\hline 26 & 254,354 & 7-O-Methylisorhamnetin & $\mathrm{C}_{17} \mathrm{H}_{13} \mathrm{O}_{7}-$ & 25.6 & 329.0627 & 329.0670 & \\
\hline 27 & 254,354 & Pelargonidin & $\mathrm{C}_{15} \mathrm{H}_{11} \mathrm{O}_{5}+$ & 25.8 & 271.0606 & 271.0618 & \\
\hline 28 & 254,354 & Isorhamnetin-3-O-glucose & $\mathrm{C}_{22} \mathrm{H}_{21} \mathrm{O}_{12}-$ & 26.1 & 477.1038 & 477.1031 & \\
\hline 29 & 254,354 & Delphinidin & $\mathrm{C}_{15} \mathrm{H}_{11} \mathrm{O}_{7}^{-}$ & 26.4 & 303.0505 & 303.0161 & \\
\hline 30 & & Phenyllactic acid hexoside & $\mathrm{C}_{15} \mathrm{H}_{17} \mathrm{O}_{5}^{-}$ & 26.9 & 327.2178 & 327.2178 & \\
\hline 31 & 254,354 & Isorhamnetin & $\mathrm{C}_{16} \mathrm{H}_{11} \mathrm{O}_{7}^{-}$ & 28.5 & 315.0238 & 315.0499 & \\
\hline 32 & 254,354 & Quercetin* & $\mathrm{C}_{15} \mathrm{H}_{9} \mathrm{O}_{7}^{-}$ & 29.9 & 301.0264 & 301,0353 & \\
\hline 33 & 254,347 & Luteolin * & $\mathrm{C}_{15} \mathrm{H}_{9} \mathrm{O}_{6}{ }^{-}$ & 30.2 & 285.0405 & 285.0392 & \\
\hline 34 & 254,354 & Cyanidin & $\mathrm{C}_{15} \mathrm{H}_{11} \mathrm{O}_{6}+$ & 31.0 & 287.0556 & 287.0569 & \\
\hline 35 & 292. 330sh & Naringenin * & $\mathrm{C}_{15} \mathrm{H}_{12} \mathrm{O}_{5}^{-}$ & 32.5 & 271.0824 & 271.0610 & \\
\hline 36 & 254,347 & Apigenin * & $\mathrm{C}_{15} \mathrm{H}_{9} \mathrm{O}_{5}^{-}$ & 34.0 & 269.0455 & 269.0443 & \\
\hline
\end{tabular}

${ }^{*}$ Identified by spiking experiments with authentic compounds; $\#=$ number; sh = shoulder. 


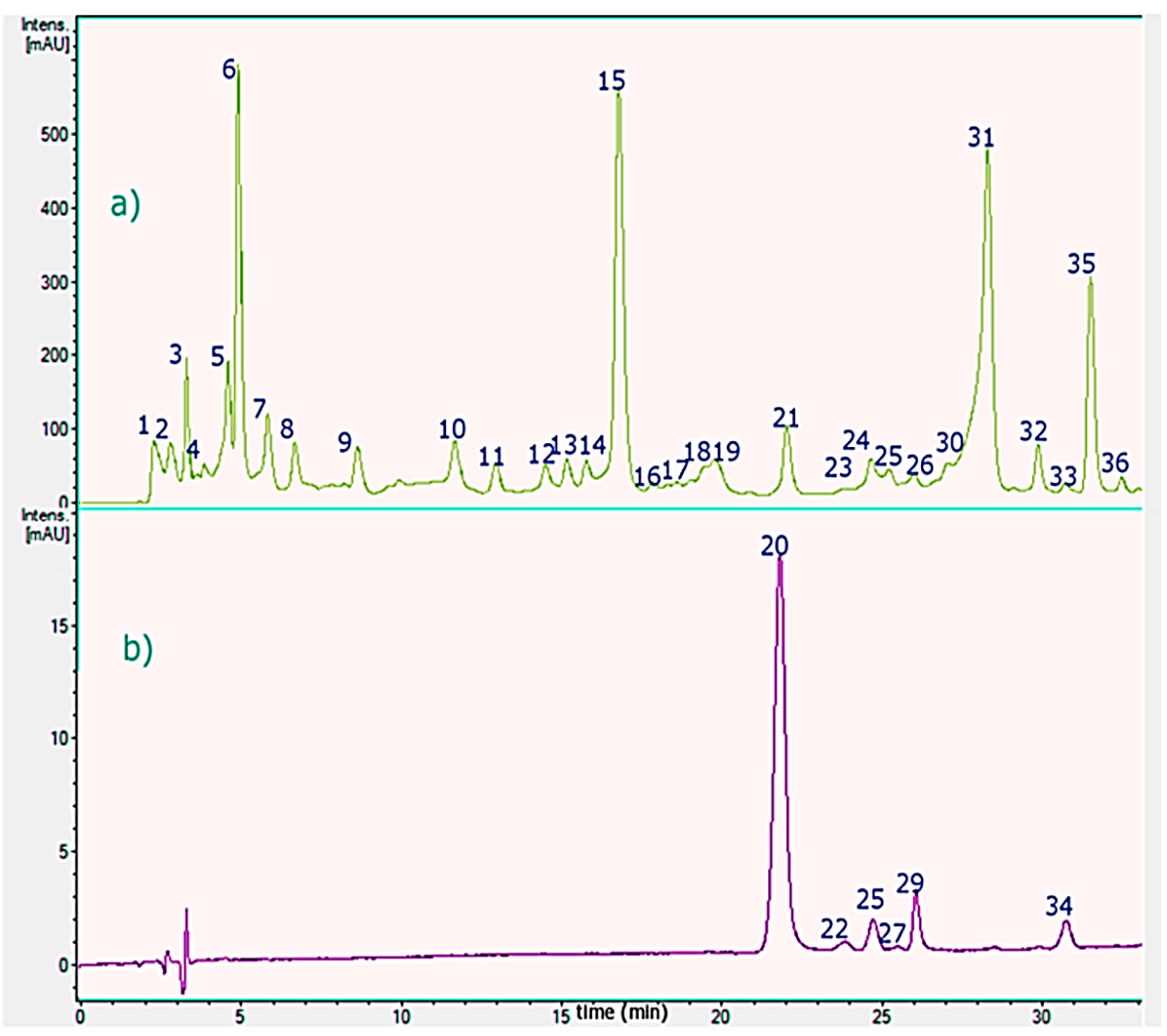

Figure 2. HPLC-PDA chromatograms of T. tetrandus from the VIII region of Chile. (a) leaves, monitored at 280; and (b) flowers, monitored at $520 \mathrm{~nm}$. Peaks numbers refer to those indicated in Table 2.

The optimal conditions for the separation of the phenolics were obtained with a fast linear gradient solvent system of $0.1 \%$ aqueous formic acid (solvent $\mathrm{A}$ ) and acetonitrile $0.1 \%$ formic acid (solvent $\mathrm{B}$ ) with a flow rate of $1.0 \mathrm{~mL} / \mathrm{min}^{-1}$ using an UHPLC $\mathrm{C}_{18}$ column as a stationary phase. Several common compounds were in the present study identified accurately using the HCD cell including proanthocyanidins, phenolic acids and flavonoids. Peaks 20, 22, 25, 27, 29 and 34 were detected in the flowers and the other peaks in the leaves. Below is the detailed explanation of the characterization. Figure 3 shows full MS spectra and structures of several compounds detected.

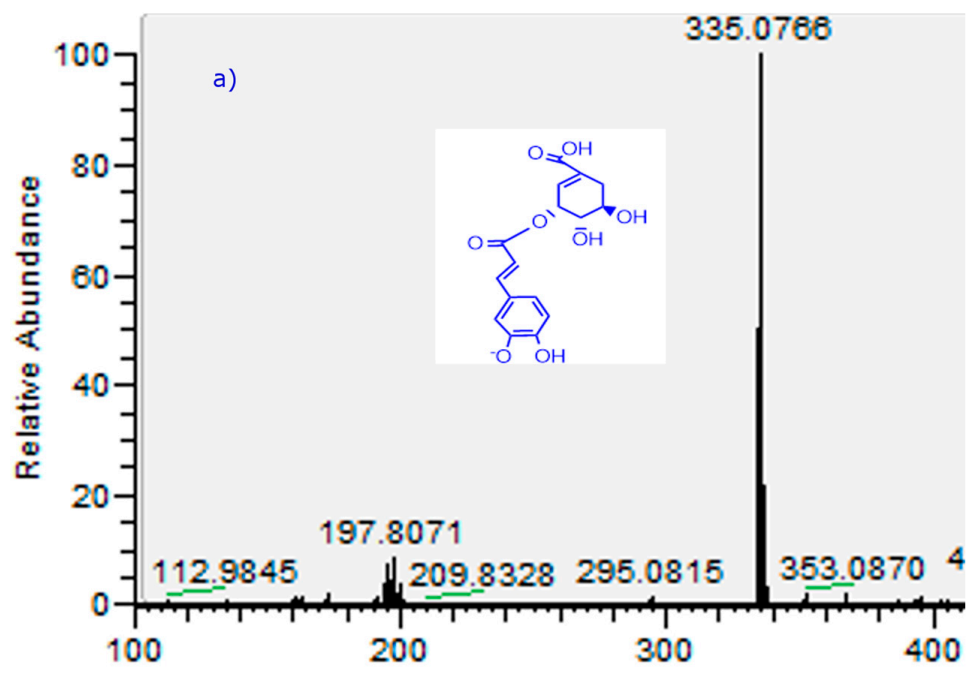

Figure 3. Cont. 

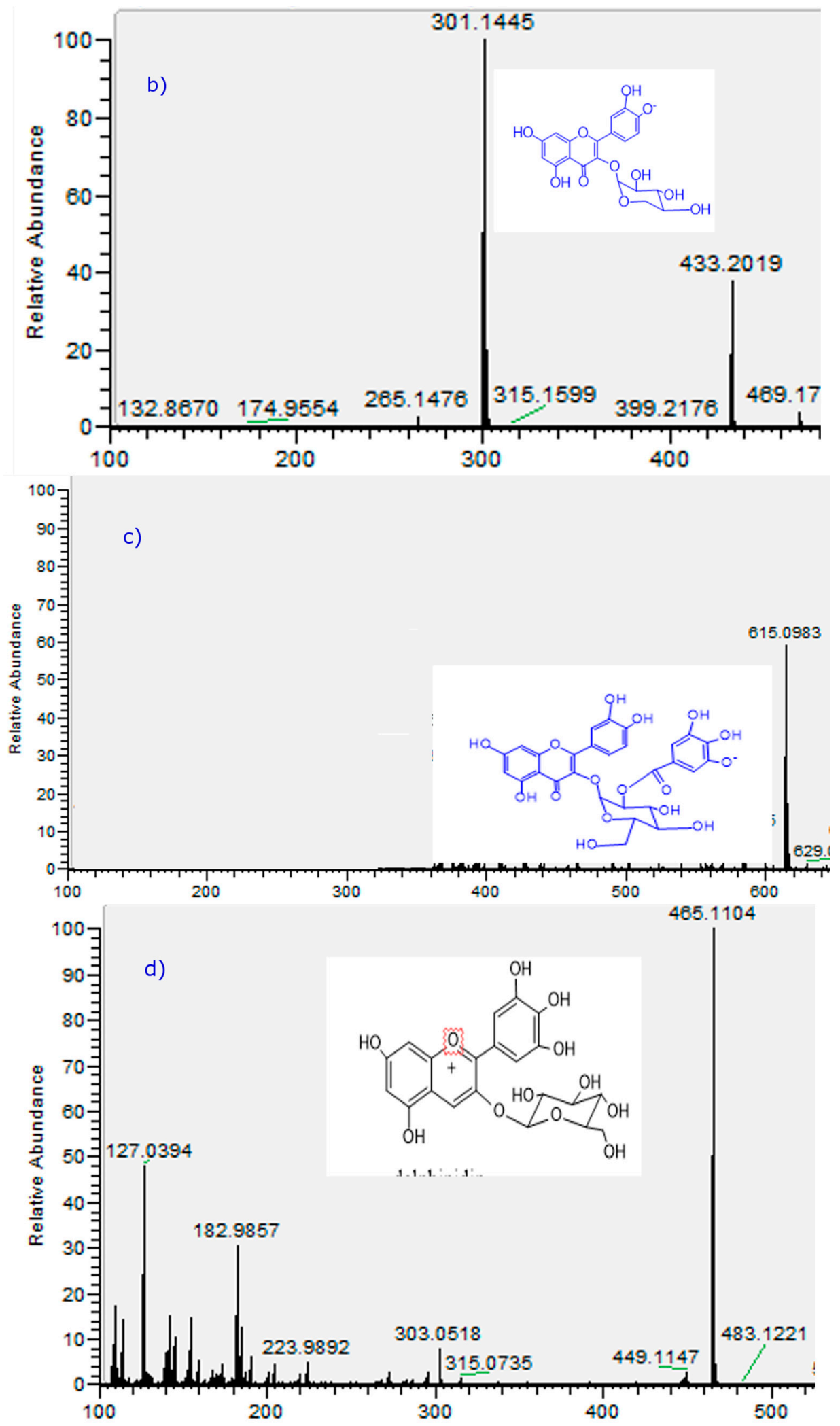

Figure 3. Cont. 

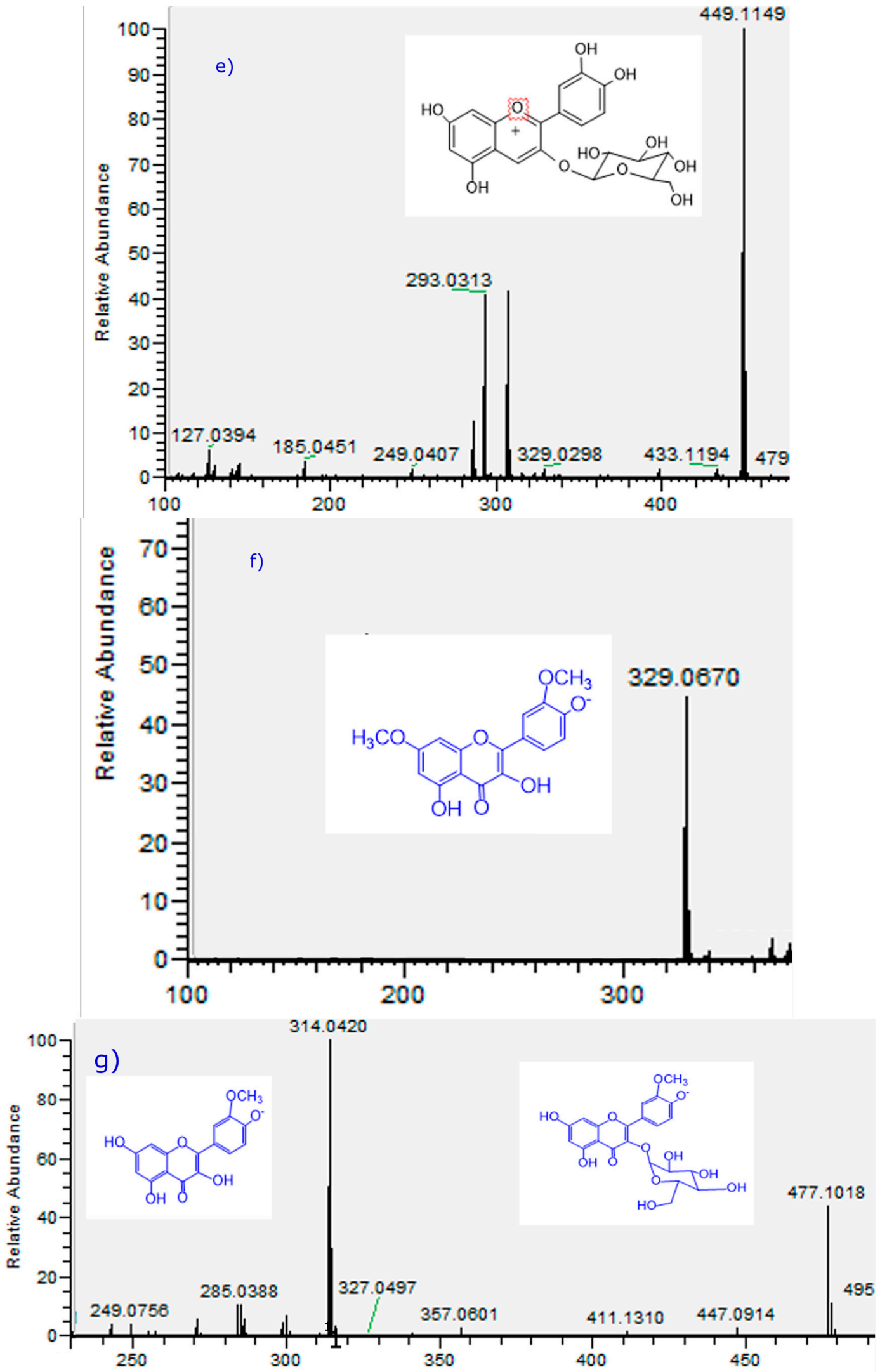

Figure 3. Cont. 


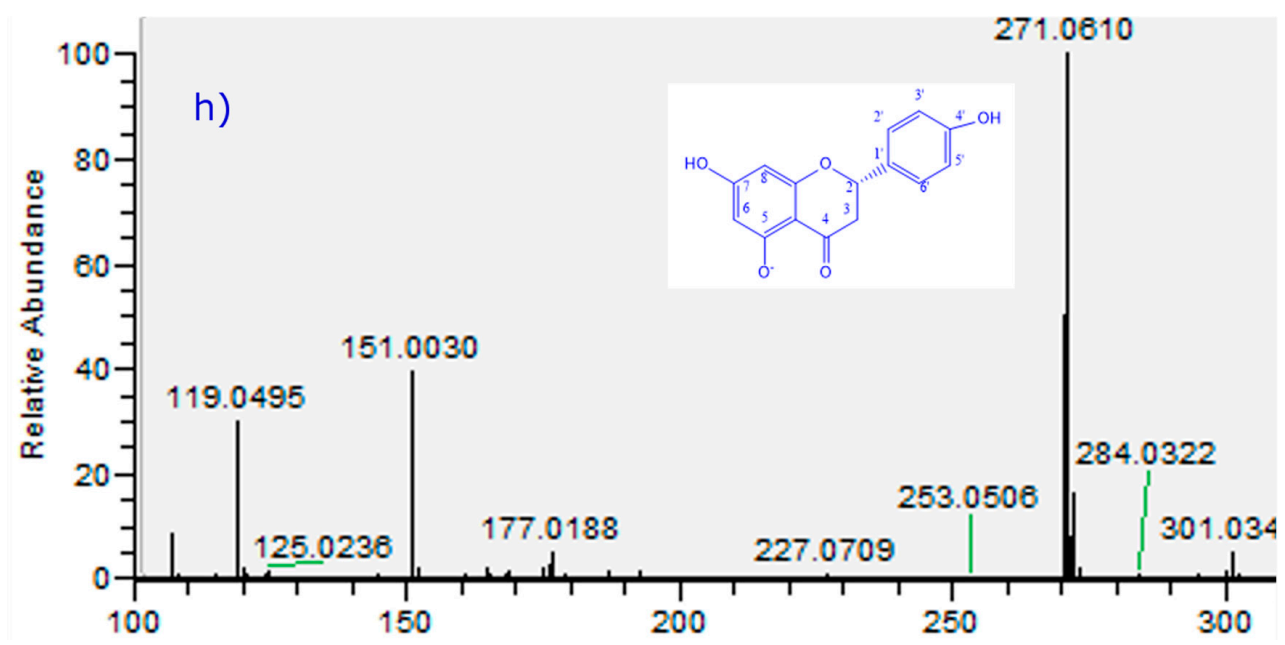

Figure 3. Full scan OT-MS ${ }^{n}$ spectra of of some representative compounds identified in T. tetrandus from Chile. (a) Peak 4; (b) peak 12; (c) Peak 15; (d) peak 20; (e) peak 22; (f) peak 26; (g) peak 28; and $(\mathbf{h})$ peak 35 . Peaks numbers refer to those indicated in Table 2.

\subsubsection{Flavonoids}

Several flavonols detected were simply aglycones and some were glycosylated. Peak 32 was identified as quercetin, while peaks 33 and 36 (ions at $m / z: 285.0392$ and 269.0443) were identified as the flavonoids luteolin and apigenin [43]. Peak 31 was identified as isorhamnetin $\left(\mathrm{C}_{16} \mathrm{H}_{11} \mathrm{O}_{7}{ }^{-}\right.$, $\lambda_{\max } 254-354 \mathrm{~nm}$ ) [44]. Peaks 26 with a [M - H] $]^{-}$ion at $m / z: 329.0670$ was identified as 7-O-methyl isorhamnetin, and peak 28 as the glycosylated isorhamnetin-3-O-glucoside [44]. Peak 35 with a $[\mathrm{M}-\mathrm{H}]^{-}$ion at $m / z: 271.0610$ was identified as the flavanone naringenin $[35,43,45]$. Peak 11 with a $[\mathrm{M}-\mathrm{H}]^{-}$ion at $m / z: 433.2019$ was identified as quercetin 3-O-pentoside. In the same manner peak 12 with a $[\mathrm{M}-\mathrm{H}]^{-}$ion at $m / z$ : 463.0876 was identified as quercetin-3-O-glucoside $\left(\mathrm{C}_{21} \mathrm{H}_{19} \mathrm{O}_{12}{ }^{-}\right)$and peak 7 as rutin [44,46] and peak 13 was identified as apiin (apigenin-apioglucoside) [47].

\subsubsection{Phenolic Acids}

Peak 1 was identified as quinic acid and peak 2 as caffeoyl-glucoside $\left(341.0870, \mathrm{C}_{15} \mathrm{H}_{17} \mathrm{O}_{9}{ }^{-}\right)$, while peak 14 as $p$-coumaroyl malate (ion at $m / z$ : 279.0507, $\mathrm{C}_{13} \mathrm{H}_{11} \mathrm{O}_{7}{ }^{-}$). Two chlorogenic acids $\left(\mathrm{C}_{16} \mathrm{H}_{18} \mathrm{O}_{9}\right)$ were identified. The isomers detected include 3-O-caffeoylquinic acid (peak 3) and 5-O-caffeoylquinic acid (neochlorogenic acid or 5-CQA, peak 17). Another peak could be tentatively identified as 3-O-feruloylquinic acid (or 3-FQA, peak 9), all of them producing a quinic acid $\mathrm{MS}^{2}$ ion at around $m / z: 191.0556$ (quinic acid $\mathrm{C}_{7} \mathrm{H}_{11} \mathrm{O}_{6}{ }^{-}$) and the CGA all produced also a $2 \mathrm{M}-\mathrm{H}$ adduct ion at around $m / z: 707$ [9]. They were also identified according to their UV spectra $\left(\lambda_{\max }\right.$ at $\left.314-330 \mathrm{~nm}\right)$. Peaks 16 and 24 with $[\mathrm{M}-\mathrm{H}]^{-}$ions at $m / z: 515.1189$ and 515.1192 were identified as di-CQA isomers according to the formula $\mathrm{C}_{25} \mathrm{H}_{23} \mathrm{O}_{12}{ }^{-}$[40]. Peak 24 with pseudomolecular ion at $m / z: 337.0356$ was identified as 3-p-Coumaroylquinic acid $\left(\mathrm{C}_{18} \mathrm{H}_{9} \mathrm{O}_{7}{ }^{-}\right)$[48]. Peak 30 was identified as phenyl lactic acid hexoside [45].

\subsubsection{Oxylipins}

Peaks 18 and 19 were tentatively identified as the antioxidant fatty acids known as oxylipins (trihydroxyoctadecadienoic acid and (trihydroxyoctadecaenoic acid, respectively) [24].

\subsubsection{Procyanidins}

Peak 6, 8 and 10 were identified as catechin, gallocatechin and epigallocatechin respectively (ions at $m / z: 289.0715,305.0304$ and 305.0301 , respectively) [39,42,44]. 


\subsubsection{Anthocyanins}

Six main known anthocyanins were identified in the flowers, peaks 20, 22, 25, 27, 29 and 34, Figure 3) with molecular ions in positive mode at $\mathrm{m} / \mathrm{z}: 465.1033$ (delphinidin-3-O-glucoside), 449.1149 (cyanidin-3-O-glucoside), 271.0620 (pelargonidin), 303.0161 (delphinidin), 331.0117 (malvidin), and 287.0571 (cyanidin) respectively. The identity was corroborated by co-elution with standard anthocyanins and literature data.

\section{Materials and Methods}

\subsection{Chemicals and Plant Material}

Folin-Ciocalteu phenol reagent $(2 \mathrm{~N})$, reagent grade $\mathrm{Na}_{2} \mathrm{CO}_{3}, \mathrm{AlCl}_{3}, \mathrm{HCl}, \mathrm{FeCl}_{3}, \mathrm{NaNO}_{2}$, $\mathrm{NaOH}$, quercetin, trichloroacetic acid, sodium acetate, HPLC-grade water, HPLC-grade acetonitrile, reagent grade $\mathrm{MeOH}$ and formic acid were obtained from Merck (Darmstadt, Germany). Malvidin, delphinidin, pelargonidin, quercetin, luteolin, apigenin, isorhamnetin, naringenin, cyanidin, delphinidin 3-O-galactoside, cyanidin-3-O-galactoside, cyanidin-3-O-glucoside, chlorogenic acid, ferulic and caffeic acids (all standards with purity higher than $95 \%$ by HPLC) were purchased either from ChromaDex (Santa Ana, CA, USA), Extrasynthèse (Genay, France) or Wuxi Apptec Co. Ltd. (Shanghai, China). Gallic acid, TPTZ (2, 4, 6-tri(2-pyridyl)-s-triazine), Trolox, tert-butylhydroperoxide, nitroblue tetrazolium, xanthine oxidase and DPPH (1,1-diphenyl-2-picrylhydrazyl radical) were purchased from Sigma-Aldrich Chemical Co. (St. Louis, MO, USA). The plant and flowers (approx. $500 \mathrm{~g}$ each, three individuals, plants hosted on a group of aspen species) were collected at Los Ángeles, Región del Bio-Bio, Chile in April 2012. Sampling was performed using sterile disposable gloves and rigid plastic sample containers and the samples (three individuals) were submitted individually by overnight courier to our laboratory in Antofagasta to prevent deterioration. A voucher herbarium specimen was deposited at the Laboratorio de Productos Naturales, Universidad de Antofagasta, Antofagasta, Chile, with the number Tt-121505.

\subsection{Sample Preparation}

Flowers and leaves (three individuals of each) were separately collected and extracted with acidified methanol and the resulting extracts were processed by solid phase extraction. Fresh flowers were carefully washed, separately homogenized in a blender and freeze-dried (Freezone Freeze dry system plus 2.5 L, Labconco Corporation, Kansas City, MO, USA). Ten grams of the lyophilized flowers and leaves were finally pulverized in a mortar, (separately) defatted thrice with $100 \mathrm{~mL}$ of $n$-hexane and then extracted with $100 \mathrm{~mL}$ of $0.1 \% \mathrm{HCl}$ in $\mathrm{MeOH}$ in the dark in an ultrasonic bath for one hour each time. The extracts from each sample were combined, filtered and evaporated in vacuo in the dark $\left(40{ }^{\circ} \mathrm{C}\right)$. The extracts were suspended in $20 \mathrm{~mL}$ ultrapure water and loaded onto an XAD-7 $(100 \mathrm{~g})$ column. The column was rinsed with water $(100 \mathrm{~mL})$ and phenolic compounds were eluted with $100 \mathrm{~mL}$ of $\mathrm{MeOH}$ acidified with $0.1 \% \mathrm{HCl}$. The solutions were combined and evaporated to dryness under reduced pressure $\left(40^{\circ} \mathrm{C}\right)$ to give $567.23 \mathrm{mg}$ and $895.3 \mathrm{mg}$ of extract from T. tetrandus leaves and flowers, respectively.

\subsection{Instrumentation}

A Thermo Scientific Dionex Ultimate 3000 UHPLC system (Thermo Fisher Scientific, Bremen, Germany) equipped with a quaternary Series RS pump and a Thermo Scientific Dionex Ultimate 3000 Series TCC-3000RS column compartments with a Thermo Fisher Scientific Ultimate 3000 Series WPS-3000RS autosampler (Thermo Fisher Scientific) and a rapid separations PDA detector controlled by Chromeleon 7.2 Software (Thermo Fisher Scientific, Waltham, MA, USA and Dionex Softron $\mathrm{GmbH}$ division of Thermo Fisher Scientific) hyphenated with a Thermo high resolution Q Exactive focus mass spectrometer (Thermo Fisher Scientific) were used for analysis. The chromatographic system was coupled to the MS with a Heated Electrospray Ionization Source II (HESI II). Nitrogen 
(purity $>99.999 \%$ ) obtained from a Genius NM32LA nitrogen generator (Peak Scientific, Billerica, MA, USA) was employed as both the collision and damping gas. Mass calibration for the Orbitrap was performed once a week, in both negative and positive modes, to ensure a working mass accuracy lowers than or equal to $5 \mathrm{ppm}$. Caffeine, $\mathrm{N}$-butylamine (Sigma-Aldrich) were the calibration standards for positive ions and buspirone hydrochloride, sodium dodecyl sulfate, and taurocholic acid sodium salt (Sigma-Aldrich) were used to calibrate the mass spectrometer. These compounds were dissolved in a mixture of acetic acid, acetonitrile, water and methanol (Merck) and were infused using a Chemyx Fusion 100 syringe pump (Thermo Fisher Scientific). Q Exactive 2.0 SP 2, XCalibur 2.3 and Trace Finder 3.2 softwares (Thermo Fisher Scientific and Dionex Softron GmbH Part of Thermo Fisher Scientific) were used for UHPLC-mass spectrometer control and data processing, respectively.

\subsection{LC Parameters}

A portion of each extract $(5 \mathrm{mg}$ ) obtained as explained above was dissolved in $5 \mathrm{~mL} 1 \%$ formic acid in $\mathrm{MeOH}$, filtered through a $0.45 \mu \mathrm{m}$ micropore membrane (PTFE, Waters Milford, MA, USA) before use and was injected into the UHPLC-PDA and ESI-orbitrap-MS equipment. Liquid chromatography was performed using an UHPLC C18 column (Acclaim, $150 \mathrm{~mm} \times 4.6 \mathrm{~mm}$ ID, $5 \mu \mathrm{m}$, Restek Corporation, Bellefonte, PA, USA) operated at $25^{\circ} \mathrm{C}$. The detection wavelengths were $254,280,320$ and $440 \mathrm{~nm}$, and PDA was recorded from 200 to $800 \mathrm{~nm}$ for peak characterization. Mobile phases were $1 \%$ formic aqueous solution (A) and acetonitrile (B). The gradient program (time ( $\mathrm{min}), \% \mathrm{~B}$ ) was: $(0.00,5)$; $(5.00,5) ;(10.00,30) ;(15.00,30) ;(20.00,70) ;(25.00,70) ;(35.00,5)$ and $12 \mathrm{~min}$ for column equilibration before each injection. The flow rate was $1.00 \mathrm{~mL} / \mathrm{min}^{-1}$, and the injection volume was $10 \mu \mathrm{L}$. Standards and extracts dissolved in methanol were kept at $10^{\circ} \mathrm{C}$ during storage in the autosampler.

\subsection{MS Parameters}

The HESI parameters were optimized as follows: sheath gas flow rate 75 units; aux. gas unit flow rate 20; capillary temperature $400{ }^{\circ} \mathrm{C}$; aux gas heater temperature $500{ }^{\circ} \mathrm{C}$; spray voltage $2500 \mathrm{~V}$ (for ESI-); and S lens RF level 30. Full scan data in both positive and negative was acquired at a resolving power of 70,000 full width half maximum (FWHM) at $m / z 200$. For the compounds of interest, a scan range of $m / z 100-1000$ was chosen; the automatic gain control (AGC) was set at $3 \times 10^{6}$ and the injection time was set to $200 \mathrm{~ms}$. Scan-rate was set at $2 \mathrm{scans} \cdot \mathrm{s}^{-1}$. External calibration was performed using a calibration solution in positive and negative modes before each sample series. In addition to the full scan acquisition method, for confirmations purposes, a targeted MS/MS analysis was performed using the mass inclusion list and expected retention times of the target analytes, with a $30 \mathrm{~s}$ time window, with the Orbitrap spectrometer operating both in positive and negative mode at $17,500 \mathrm{FWHM}(\mathrm{m} / z 200)$. The AGC target was set to $2 \times 10^{5}$, with the maximum injection time of $20 \mathrm{~ms}$. The precursor ions are filtered by the quadrupole which operates at an isolation window of $m / z 2$. The fore vacuum, high vacuum and ultrahigh vacuum were maintained at approximately 2 mbar, from 105 to below 1010 mbar, respectively. Collision energy (HCD cell) was operated at $30 \mathrm{kv}$. Detection was based on calculated exact mass and on retention time of target compounds, presented in Table 2. The mass tolerance window was set to $5 \mathrm{ppm}$ for the two analysis modes.

\subsection{Antioxidant Assays}

\subsubsection{Ferric Reducing Antioxidant Power}

The determination of ferric reducing antioxidant power or ferric reducing ability (FRAP assay) of the extracts was performed as described by [49] with some modifications. The stock solutions prepared were $300 \mathrm{mM}$ acetate buffer pH 3.6, $10 \mathrm{mM}$ TPTZ (2,4,6-tri (2-pyridyl)-s-triazine) solution in $40 \mathrm{mM}$ $\mathrm{HCl}$, and $20 \mathrm{mM} \mathrm{FeCl} \cdot 6 \mathrm{H}_{2} \mathrm{O}$ solution. Plant extracts or standard methanolic Trolox solutions $(150 \mu \mathrm{L})$ were incubated at $37^{\circ} \mathrm{C}$ with $2 \mathrm{~mL}$ of the FRAP solution (prepared by mixing $25 \mathrm{~mL}$ acetate buffer, $5 \mathrm{~mL}$ TPTZ solution, and $10 \mathrm{~mL} \mathrm{FeCl}_{3} \cdot 6 \mathrm{H}_{2} \mathrm{O}$ solution) for $30 \mathrm{~min}$ in the dark. Absorbance of the blue 
ferrous tripyridyltriazine complex formed was then read at $593 \mathrm{~nm}$. Quantification was performed using a standard calibration curve of antioxidant Trolox (from 0.2 to $2.5 \mu \mathrm{mol} / \mathrm{mL}, R^{2}: 0.995$ ). Samples were analyzed in triplicate and results are expressed in $\mu \mathrm{mol} \mathrm{TE} / 100$ grams fresh mass.

\subsubsection{Superoxide Anion Scavenging Activity}

The enzyme xanthine oxidase is able to generate superoxide anion radical $\left(\mathrm{O}_{2}{ }^{-}\right)$"in vivo" by oxidation of reduced products from intracellular ATP metabolism. The superoxide anion generated in this reaction sequence reduces the nitro blue tetrazolium dye (NBT), leading to a chromophore with a maximum of absorption at $560 \mathrm{~nm}$. Superoxide anion scavengers reduce the speed of generation of the chromophore. The superoxide anion scavenging activities of isolated compounds and fractions were measured spectrophotometrically in a microplate reader as reported previously [24]. All extracts were evaluated at $100 \mu \mathrm{g} / \mathrm{mL}$. Values are presented as mean \pm standard deviation of three determinations.

\subsection{Polyphenol and Flavonoids Contents}

The total polyphenolic contents (TPC) of mistletoe were determined by the Folin-Ciocalteau method $[25,26,50]$ with some modifications. An aliquot of each processed SPE extract $(200 \mu \mathrm{L}$, approx. $2 \mathrm{mg} / \mathrm{mL})$ was added to the Folin-Ciocalteau reagent $(2 \mathrm{~mL}, 1: 10 v / v$ in purified water $)$ and after $5 \mathrm{~min}$ of reaction at room temperature $\left(25^{\circ} \mathrm{C}\right), 2 \mathrm{~mL}$ of a $100 \mathrm{~g} / \mathrm{L}$ solution of $\mathrm{Na}_{2} \mathrm{CO}_{3}$ was added. Sixty minutes later the absorbance was measured at $710 \mathrm{~nm}$. The calibration curve was performed with gallic acid (concentrations ranging from 16 to $500 \mu \mathrm{g} / \mathrm{mL}, R^{2}=0.999$ ) and the results were expressed as $\mathrm{mg}$ gallic acid equivalents $/ 100 \mathrm{~g}$ fresh mass. Determination of total flavonoid content (TFC) of the methanolic extracts was performed as reported previously [51] using the $\mathrm{AlCl}_{3}$ colorimetric method. Quantification was expressed by reporting the absorbance in the calibration graph of quercetin, which was used as a standard (from 0.1 to $65.0 \mu \mathrm{g} / \mathrm{mL}, R^{2}=0.994$ ). Results are expressed as mg quercetin equivalents/g fresh weight. All spectrometric measurements were performed using a Unico 2800 UV-vis spectrophotometer (Unico Instruments, Co, Ltd., Shanghai, China).

\subsection{Statistical Analysis}

The statistical analysis was carried out using the originPro 9.0 software packages (Originlab Corporation, Northampton, MA, USA). The determination was repeated at least three times for each sample solution. Analysis of variance was performed using ANOVA. Significant differences between means were determined by Tukey comparison test ( $p$ values $<0.05$ were regarded as significant).

\section{Conclusions}

Thirty six compounds including several caffeoyl acids (peaks 2, 3, 4, 9, 16, 17, and 24) three procyanidins (peaks 6,8 and 10), several flavonols (peaks 11, 12, 15, 21, 23, 26, 28, 31-36) two oxylipins (peaks 18 and 19) were detected in the leaves and six anthocyanins (peaks 22, 25, 26, 27, 29 and 34) were detected in the flowers of a native mistletoe from the VIII region of Chile using PDA and Orbitrap-ESI-MS for the first time. However, significant differences in the total phenolic content and antioxidant activity were found between these two plant parts, probably due to the quantity of phenolic compounds detected. The mistletoe leaves showed the highest antioxidant activity measured as the bleaching of the DPPH radical, the ferric reducing antioxidant power and superoxide anion scavenging activity $(13.38 \pm 0.47 \mu \mathrm{g} / \mathrm{mL}, 125.32 \pm 5.96 \mu \mathrm{mol} \mathrm{TE} / \mathrm{g}$ DW and $84.06 \pm 4.59$ at $100 \mu \mathrm{g} / \mathrm{mL}$, respectively). The mistletoe is thus a good candidate for industrial crop production and has also the potential to produce nutraceuticals.

Acknowledgments: This work was financially supported by FONDECYT (grants No. 1140178 and 1150745) and Universidad Arturo Prat (Iquique, Chile; VRIIP0113-15). We also acknowledge Fondequip (grant EQM140002) for the funding to purchase the UHPLC Orbitrap MS equipment. We also thank to the SAG (Servicio Agrícola y Ganadero) and Corporación Nacional Forestal of Chile (CONAF) for allowing us to collect plants and fruits in the national protected areas of Chile belonging to SNASPE (National System of Protected Areas of Chile). 
Author Contributions: Important contributions to the design of the manuscript: B.S. and C.Q. Sample and analysis experiments: B.S., M.S. and C.Q. Analysis of the experimental data: C.A. Critically revising the manuscript for important intellectual content: M.S. and C.A. All authors helped with the preparation of the manuscript and approved the final version.

Conflicts of Interest: The authors declare no conflict of interest.

\section{References}

1. Burgos, A.N.; Morales, M.A. Qualitative study of use medicinal plants in a complementary or alternative way with the use of among of rural population of the Bulnes City, Bío-Bío Region, Chile. BLCPMA 2010, 9, 377-387.

2. De Mösbach, E.W. Botánica Indígena de Chile. In Museo Chileno de Arte Precolombino, Fundación Andes y Editorial Andrés Bello; Aldunate, C., Villagrán Santiago, C., Eds.; Andres Bello: Santiago, Chile, 1991; pp. 95-96.

3. Hoffmann, A.; Arroyo, M.T.K.; Liberona, F.; Muñoz, M.; Watson, J.M. Plantas Altoandinas en la Flora Silvestre de Chile; ediciones Fundación Claudio A. Gay: Santiago de Chile, Chile, 2000.

4. De Pascual-Teresa, S.; Sanchez-Ballesta, M.T. Anthocyanins: From plant to health. Phytochem. Rev. 2008, 7, 281-299. [CrossRef]

5. Nile, S.H.; Park, S.W. Edible berries: Bioactive components and their effect on human health. Nutrition 2014, 30, 134-144. [CrossRef] [PubMed]

6. Woodward, G.; Kroon, P.; Cassidy, A.; Kay, C. Anthocyanin stability and recovery: Implications for the analysis of clinical and experimental samples. J. Sci. Food Agric. 2009, 57, 5271-5278. [CrossRef] [PubMed]

7. Hou, D.X. Potential mechanisms of cancer chemoprevention by anthocyanins. Curr. Mol. Med. 2003, 3, 149-159. [CrossRef] [PubMed]

8. Matsui, T.; Ebuchi, S.; Kobayashi, M.; Fukui, K.; Sugita, K.; Terahara, N.; Matsumoto, K. Anti-hyperglycemic effect of diacylated anthocyanin derived from Ipomoea batatas cultivar Ayamurasaki can be achieved through the $\alpha$-glucosidase inhibitory action. J. Agric. Food Chem. 2002, 50, 7244-7248. [CrossRef] [PubMed]

9. Simirgiotis, M.J.; Silva, M.; Becerra, J.; Schmeda-Hirschmann, G. Direct characterisation of phenolic antioxidants in infusions from four Mapuche medicinal plants by liquid chromatography with diode array detection (HPLC-DAD) and electrospray ionisation tandem mass spectrometry (HPLC-ESI-MS). Food Chem. 2012, 131, 318-327. [CrossRef]

10. Brito, A.; Ramirez, J.E.; Areche, C.; Sepúlveda, B.; Simirgiotis, M.J. HPLC-UV-MS Profiles of Phenolic Compounds and Antioxidant Activity of Fruits from Three Citrus Species Consumed in Northern Chile. Molecules 2014, 19, 17400-17421. [CrossRef] [PubMed]

11. Lea, M.A. Flavonol Regulation in Tumor Cells. J. Cell. Biochem. 2015, 116, 1190-1194. [CrossRef] [PubMed]

12. Wang, Y.; Han, A.; Chen, E.; Singh, R.K.; Chichester, C.O.; Moore, R.G.; Singh, A.P.; Vorsa, N. The cranberry flavonoids PAC DP-9 and quercetin aglycone induce cytotoxicity and cell cycle arrest and increase cisplatin sensitivity in ovarian cancer cells. Int. J. Oncol. 2015, 46, 1924-1934. [PubMed]

13. Steinmann, D.; Ganzera, M. Recent advances on HPLC/MS in medicinal plant analysis. J. Pharm. Biomed. Anal. 2011, 55, 744-757. [CrossRef] [PubMed]

14. Wright, P. Metabolite identification by mass spectrometry: Forty years of evolution. Xenobiotica 2011, 41, 670-686. [CrossRef] [PubMed]

15. Mattoli, L.; Cangi, F.; Ghiara, C.; Burico, M.; Maidecchi, A.; Bianchi, E.; Ragazzi, E.; Bellotto, L.; Seraglia, R.; Traldi, P. A metabolite fingerprinting for the characterization of commercial botanical dietary supplements. Metabolomics 2011, 7, 437-445. [CrossRef]

16. Aliferis, K.A.; Chrysayi-Tokousbalides, M. Metabolomics in pesticide research and development: Review and future perspectives. Metabolomics 2011, 7, 35-53. [CrossRef]

17. Kang, H.J.; Yang, H.J.; Kim, M.J.; Han, E.S.; Kim, H.J.; Kwon, D.Y. Metabolomic analysis of meju during fermentation by ultra performance liquid chromatography-quadrupole-time of flight mass spectrometry (UPLC-Q-TOF MS). Food Chem. 2011, 127, 1056-1064. [CrossRef] [PubMed]

18. Martínez-Domínguez, G.; Romero-González, R.; Garrido Frenich, A. Multi-class methodology to determine pesticides and mycotoxins in green tea and royal jelly supplements by liquid chromatography coupled to Orbitrap high resolution mass spectrometry. Food Chem. 2016, 197, 907-915. [CrossRef] [PubMed]

19. Hao, C.; Zhao, X.; Yang, P. GC-MS and HPLC-MS analysis of bioactive pharmaceuticals and personal-care products in environmental matrices. TrAC 2007, 26, 569-580. [CrossRef] 
20. Maoka, T. Recent progress in structural studies of carotenoids in animals and plants. Arch. Biochem. Biophys. 2009, 483, 191-195. [CrossRef] [PubMed]

21. Barnes, J.S.; Nguyen, H.P.; Shen, S.; Schug, K.A. General method for extraction of blueberry anthocyanins and identification using high performance liquid chromatography-electrospray ionization-ion trap-time of flight-mass spectrometry. J. Chromatogr. A 2009, 1216, 4728-4735. [CrossRef] [PubMed]

22. Fischer, U.A.; Carle, R.; Kammerer, D.R. Identification and quantification of phenolic compounds from pomegranate (Punica granatum L.) peel, mesocarp, aril and differently produced juices by HPLC-DAD-ESI/MS(n). Food Chem. 2011, 127, 807-821. [CrossRef] [PubMed]

23. He, D.X.; Shan, Y.; Wu, Y.H.; Liu, G.Z.; Chen, B.; Yao, S.Z. Simultaneous determination of flavanones, hydroxycinnamic acids and alkaloids in citrus fruits by HPLC-DAD-ESI/MS. Food Chem. 2011, 127, 880-885. [CrossRef] [PubMed]

24. Simirgiotis, M.J.; Ramirez, J.E.; Schmeda Hirschmann, G.; Kennelly, E.J. Bioactive coumarins and HPLC-PDA-ESI-ToF-MS metabolic profiling of edible queule fruits (Gomortega keule), an endangered endemic Chilean species. Food Res. Int. 2013, 54, 532-543. [CrossRef]

25. Simirgiotis, M.J.; Borquez, J.; Schmeda-Hirschmann, G. Antioxidant capacity, polyphenolic content and tandem HPLC-DAD-ESI/MS profiling of phenolic compounds from the South American berries Luma apiculata and L. chequen. Food Chem. 2013, 139, 289-299. [CrossRef] [PubMed]

26. Simirgiotis, M.J. Antioxidant Capacity and HPLC-DAD-MS Profiling of Chilean Peumo (Cryptocarya alba) Fruits and Comparison with German Peumo (Crataegus monogyna) from Southern Chile. Molecules 2013, 18, 2061-2080. [CrossRef] [PubMed]

27. Bórquez, J.; Kennelly, E.J.; Simirgiotis, M.J. Activity guided isolation of isoflavones and hyphenated HPLC-PDA-ESI-ToF-MS metabolome profiling of Azorella madreporica Clos. from northern Chile. Food Res. Int. 2013, 52, 288-297. [CrossRef]

28. Simirgiotis, M.J.; Vallejos, J.; Areche, C.; Sepúlveda, B. Concise and Straightforward Asymmetric Synthesis of a Cyclic Natural Hydroxy-Amino Acid. Molecules 2014, 19, 19516-19531. [CrossRef] [PubMed]

29. Plazas, M.; López-Gresa, M.P.; Vilanova, S.; Torres, C.; Hurtado, M.; Gramazio, P.; Andújar, I.; Herráiz, F.J.; Bellés, J.M.; Prohens, J. Diversity and Relationships in Key Traits for Functional and Apparent Quality in a Collection of Eggplant: Fruit Phenolics Content, Antioxidant Activity, Polyphenol Oxidase Activity, and Browning. J. Agric. Food Chem. 2013, 61, 8871-8879. [CrossRef] [PubMed]

30. López-Gresa, M.P.; Torres, C.; Campos, L.; Lisón, P.; Rodrigo, I.; Bellés, J.M.; Conejero, V. Identification of defence metabolites in tomato plants infected by the bacterial pathogen Pseudomonas syringae. Environ. Exp. Bot. 2011, 74, 216-228. [CrossRef]

31. Hong, S.M.; Choi, J.-H.; Jo, S.-J.; Song, S.K.; Lee, J.M.; Kusakabe, T. Expression of Recombinant Viscum Album Coloratum lectin B-chain in the Silkworm Expression System and Evaluation of Antioxidant Activity. Biotech. Bioproc. Eng. 2015, 20, 515-522. [CrossRef]

32. Orhan, D.D.; Senol, F.S.; Hosbas, S.; Orhan, I.E. Assessment of cholinesterase and tyrosinase inhibitory and antioxidant properties of Viscum album L. samples collected from different host plants and its two principal substances. Ind.Crops Prod. 2014, 62, 341-349. [CrossRef]

33. Pietrzak, W.; Nowak, R.; Olech, M. Effect of extraction method on phenolic content and antioxidant activity of mistletoe extracts from Viscum album subsp abietis. Chem. Pap. 2014, 68, 976-982. [CrossRef]

34. Raieviawati, S.I.; Ishmaru, K.; Hou, D.-X.; Hayashi, N. Antioxidant Activity and Phenolic Content of Mistletoe Extracts Following High-Temperature Batch Extraction. Food Sci. Technol. Res. 2014, 20, 201-206.

35. Simirgiotis, M.J.; Benites, J.; Areche, A.; Sepulveda, B. Antioxidant capacities and analisis of phenolic compounds in three endemic Nolana species by HPLC-PDA-ESI-MS. Molecules 2015, 20, 11490-11507. [CrossRef] [PubMed]

36. Donno, D.; Beccaro, G.L.; Mellano, M.G.; Cerutti, A.K.; Bounous, G. Medicinal plants, chemical composition and quality: May blackcurrant buds and blackberry sprouts be a new polyphenol source for herbal preparations? J. Appl. Bot. Food Qual. 2013, 86, 79-89.

37. Donno, D.; Beccaro, G.L.; Mellano, M.G.; Cerutti, A.K.; Bounous, G. Goji berry fruit (Lycium spp.): Antioxidant compound fingerprint and bioactivity evaluation. J. Funct. Foods 2015, 18, 1070-1085. [CrossRef]

38. Ye, F.; Liang, Q.; Li, H.; Zhao, G. Solvent effects on phenolic content, composition, and antioxidant activity of extracts from florets of sunflower (Helianthus annuus L.). Ind. Crops Prod. 2015, 76, 574-581. [CrossRef] 
39. Brito, A.; Areche, C.; Se’́púlveda, B.; Kennelly, E.J.; Simirgiotis, M.J. Anthocyanin characterization, total phenolic quantification and antioxidant features of some Chilean berries extracts. Molecules 2014, 19, 10936-10955. [CrossRef] [PubMed]

40. Abu-Reidah, I.M.; Ali-Shtayeh, M.S.; Jamous, R.M.; Arráez-Román, D.; Segura-Carretero, A. HPLC-DAD-ESI-MS/MS screening of bioactive components from Rhus coriaria L. (Sumac) fruits. Food Chem. 2015, 166, 179-191. [CrossRef] [PubMed]

41. Benvenuti, S.; Pellati, F.; Melegari, M.; Bertelli, D. Polyphenols, Anthocyanins, Ascorbic Acid, and Radical Scavenging Activity of Rubus, Ribes, and Aronia. J. Food Sci. 2004, 69, FCT164-FCT169. [CrossRef]

42. Simirgiotis, M.J.; Schmeda-Hirschmann, G. Determination of phenolic composition and antioxidant activity in fruits, rhizomes and leaves of the white strawberry (Fragaria chiloensis spp. chiloensis form chiloensis) using HPLC-DAD-ESI-MS and free radical quenching techniques. J. Food Compos. Anal. 2010, 23, 545-553. [CrossRef]

43. Ye, M.; Yang, W.-Z.; Liu, K.-D.; Qiao, X.; Li, B.-J.; Cheng, J.; Feng, J.; Guo, D.-A.; Zhao, Y.-Y. Characterization of flavonoids in Millettia nitida var. hirsutissima by HPLC/DAD/ESI-MSn. J. Pharm. Anal. 2012, 2, 35-42. [CrossRef]

44. Simirgiotis, M.J.; Quispe, C.; Bórquez, J.; Areche, C.; Sepúlveda, B. Fast Detection of Phenolic Compounds in Extracts of Easter Pears (Pyrus communis) from the Atacama Desert by Ultrahigh-Performance Liquid Chromatography and Mass Spectrometry (UHPLC-Q/Orbitrap/MS/MS). Molecules 2016, 21, 92. [CrossRef] [PubMed]

45. Beelders, T.; de Beer, D.; Stander, M.A.; Joubert, E. Comprehensive phenolic profiling of Cyclopia genistoides (L.) Vent. by LC-DAD-MS and -MS/MS reveals novel xanthone and benzophenone constituents. Molecules 2014, 19, 11760-11790. [CrossRef] [PubMed]

46. Simirgiotis, M.J.; Theoduloz, C.; Caligari, P.D.S.; Schmeda-Hirschmann, G. Comparison of phenolic composition and antioxidant properties of two native Chilean and one domestic strawberry genotypes. Food Chem. 2009, 113, 377-385. [CrossRef]

47. Bensouici, C.; Kabouche, A.; Karioti, A.; Ozturk, M.; Duru, M.E.; Bilia, A.R.; Kabouche, Z. Compounds from Sedum caeruleum with antioxidant, anticholinesterase, and antibacterial activities. Pharm. Biol. 2016, 54, 174-179. [CrossRef] [PubMed]

48. Kolniak-Ostek, J.; Oszmiański, J. Characterization of phenolic compounds in different anatomical pear (Pyrus communis L.) parts by ultra-performance liquid chromatography photodiode detector-quadrupole/time of flight-mass spectrometry (UPLC-PDA-Q/TOF-MS). Int. J. Mass Spect. 2015, 392, 154-163. [CrossRef]

49. Benzie, I.F.F.; Strain, J.J. The ferric reducing ability of plasma (FRAP) as a measure of "Antioxidant Power": The FRAP assay. Anal. Biochem. 1996, 239, 70-76. [CrossRef] [PubMed]

50. Simirgiotis, M.J.; Caligari, P.D.S.; Schmeda-Hirschmann, G. Identification of phenolic compounds from the fruits of the mountain papaya Vasconcellea pubescens A. DC. grown in Chile by liquid chromatography-UV detection-mass spectrometry. Food Chem. 2009, 115, 775-784. [CrossRef]

51. Simirgiotis, M.J.; Adachi, S.; To, S.; Yang, H.; Reynertson, K.A.; Basile, M.J.; Gil, R.R.; Weinstein, I.B.; Kennelly, E.J. Cytotoxic chalcones and antioxidants from the fruits of Syzygium samarangense (Wax Jambu). Food Chem. 2008, 107, 813-819. [CrossRef] [PubMed]

Sample Availability: Samples of the plant material and extracts are available from the authors.

(C) 2016 by the authors; licensee MDPI, Basel, Switzerland. This article is an open access article distributed under the terms and conditions of the Creative Commons by Attribution (CC-BY) license (http:/ / creativecommons.org/licenses/by/4.0/). 